\title{
The echo of Nuremberg: Nazi data and ethics
}

\author{
Stephen G Post Case Western Reserve University, Ohio, USA
}

\section{Author's abstract}

Over the past two years, debate about the use of data taken from Nazi concentration camp experiments has intensified. Many survivors of the Holocaust have been particularly offended at the publication of hypothermia or other data. This article argues against the use of unethically obtained data, and considers the debate from the perspective of the rights of Holocaust victims.

\section{The background}

In the winter of 1949, the American, Reinhold Niebuhr, wrote these words: 'The war trials in Tokyo and Nuremberg continue, like some morning echo of last night's nightmare' (1). It is fitting that we remind ourselves of Nuremberg, now forty years old, and reflect on its continuing moral significance. The actions of the Nazi doctors and the judgements of Nuremberg are still morally relevant as indicators of how a great profession can degenerate so totally.

Recent historical research indicates that these doctors were not drawn into the moral abyss of cruelty and torture against their wills, or by the force of political ideological manipulation. Rather, they intimately partook in the theorising, planning, and executing of Nazi racial policies from the very beginning $(2,3,4,5)$. As early as the turn of the century, doctors began to develop the discipline of racial hygienics; in the Nazi Party they found sympathetic listeners and therefore joined early in higher numbers proportionately than the general population. Aryan supremacy and racial hygiene went hand in hand $(3,4)$. The doctors were not the victims of the Nazi ideology and party, but rather active and responsible agents committed to hygienic theories with roots in Social Darwinism.

Readers will already be familiar with the atrocious dossier of Nazi experiments ranging from surgical mutilation to phosgene gas exposure. The data was recorded in German wartime medical journals, and has been cited extensively in the scientific literature since

\section{Key words}

Nazi data; victims; future research. then (6). Kristine Moe has described continued use of Nazi figures from hypothermia experiments performed at Dachau (7). There are over forty-five research articles written since 1945 using Nazi data, principally specific to hypothermia $(7,8,9)$. For example, a Canadian scientist uses Nazi cooling curves in order to test survival suits and to determine survival times for those lost at sea.

This article argues (a) that as a prima facie duty unethically obtained data should never be used, (b) that such data should be expunged from published works insofar as possible, (c) that the editors of all journals that have in the past published Nazi data without a statement of moral condemnation should print such a statement now, and (d) that science should at a moral minimum be sensitive to the emotions of the victims from whom it has pillaged data.

\section{Continuing relevance}

It is important to address the Nazi issue because despite Nuremberg, German medicine has not fully denounced the moral abyss. Indeed, only recently German medical students discovered that anatomical specimens from the victims of Nazi experimentation are still in use at various universities, including Heidelberg and the Max Planck Institute of Brain Research (10). The barring of Dr Hartmut HanauskeAbel from medical practice by the German Chamber of Physicians for writing From Nazi Holocaust to Nuclear Holocaust in the English journal, the Lancet (11), indicates that there is still a considerable amount of professional denial and suppression of the Nazi experiments in Germany.

It is also important to take up the Nazi data issue because medicine as a whole has a poor moral record regarding human experimentation, as is well known. Researchers must come to an absolutely clear understanding that unethical human experimentation in the name of scientific progress is never justifiable, and that the Nazi experience has partial roots in this doctrine of progress (3). Unethical experimentation occurred very widely prior to Nuremberg in leading scientific nations. When the American doctor Andrew C Ivy was called as an expert witness at Nuremberg, he articulated principles of informed consent and nonmaleficence supposedly characteristic of 
experimentation policies in the United States (12). But we know full well that in the United States, a number of atrocious experiments were being carried out against blacks, native American Indians, and prisoners (13), and that these extended well past 1949.

At Nuremberg, the possible use of Nazi data was not considered. The Prosecution, General Telford Taylor, included this statement in his introduction to the case against the German doctors in December of 1946: 'Here we leave behind all semblance, however fictitious, of science and research' (12). But there is reason to believe that this assertion was more an expression of moral revulsion than of scientific fact, for Taylor later adds: 'These experiments revealed nothing which civilised medicine can use' (12). Other than this statement, there is no comment at all on the data's use. This was no small oversight, and its troubling repercussions remain with us 'like some morning echo of last night's nightmare' (1).

\section{Moral analysis}

Because the Nazi experiments on human beings were so appallingly unethical, it follows, prima facie, that the use of their results is unethical. General Taylor indicated this when he stated that 'civilised medicine' cannot use such morally tainted data. Many will claim categorically that the data should never be used because the experiments were intrinsically evil; they will proclaim that: ' $I$, as a member of the healing profession, never want to have anything to do with this data'. This was Beecher's blunt conclusion regarding unethically obtained data in general: 'It is my view that such material should not be published' (13). Such data, like evidence obtained illegally and judged inadmissible in a court of law, would if used corrupt the institution of medicine itself.

To articulate why use of tainted data is morally revolting, I will employ here the term 'abomination', used among cultural anthropologists to designate how all societies set boundaries to avoid contact with what is extremely and totally horrid. Abomination as a cultural concept has to do with establishing the line between civilisation and the moral abyss (the summum malum) around which ethics builds fences. What is so offensive about using the body parts of Nazi victims at German medical schools? One may as well ask why the world judged it abominable when the Nazis allegedly made lampshades out of the skin of their victims.

It is a moral intuition that such tainted goods, even if useful, are steeped in such a degree of moral failure that their use is a grave profanity under all circumstances. Our common moral response is to look aghast at those who would benefit from atrocity. The practice of salvaging good from such evil, it might be said, brings medicine into touch with the untouchable. Of course much of our experience is tainted by degrees of past moral transgression but the Holocaust, as the epitome of evil, is that place at which we invoke the symbolism of abomination.

Ideally, all reference to Nazi data would be expunged from textbooks and future journal publications in order more forcefully to impress future researchers that unethically obtained data will never see the light of print. Yet the data is already a fixture in the research literature, and cannot be 'unlearned'. At least the journals that have published the data should issue a clear condemnation of the means by which it was obtained and should avoid using such data in the future. Just as the state of Israel now calls on the German universities to apologise for using victims' body parts and tissues over the past four decades and return what parts remain for burial, so also should the Nazi data be as much as possible buried forever.

Such condemnations serve the useful purpose of discouraging young researchers from engaging in unethical experimentation. They send the powerful message that the ends do not justify the means and that unethically obtained data must benefit absolutely no one, including the ambitious researcher.

\section{Harming the victims anew}

If medical science ever insists on using unethically obtained data - a mistake, in my view - this should at least not be done without the consent of the victims. It is reasonable to think, taking one example among many, that blacks abused in American medical studies on syphilis conducted at Tuskeegee would find any use of such data both morally repulsive and a continuation of past injustice. Their veto should be respected, for to override them would be to violate consent and inflict harm doubly, ie, not only in the experimental process itself, but in its aftermath.

Yet it is precisely in the aftermath of unethical experimentation that some opportunity to restore respect for the autonomy and dignity of the victims presents itself. To use the data without the consent of those who were violated is to violate the violated anew. Therefore, those who have been experimented on without consent have the ultimate right and authority to pass final judgement on the fate of data, whether it is useful or not.

Many survivors of the Nazi experiments deeply resent the use of hypothermia and other data. Minimally, science should not proceed to use Nazi data without the consent of Holocaust victims, though even consent would not justify use insofar as any usage sends the wrong message to future scientists, as I have argued.

\section{Final remarks and a remote exception}

Although this is clearly not the case, we might hypothesise that buried within the Nazi data lies a cure for AIDS or cancer. Then the victims might want to put aside the wickedness and to forgive, as it is the true prerogative of those who have been injured to do so. This condition having been met, science might then proceed to make use of the data, although with a firm sense of compunction over transgressing the prima facie duty not to use data obtained unethically.

However, it is certain that the Nazi data does not 
promise a cure for cancer or some other major disease. When some Holocaust survivors say that the data might as well be used if it would benefit humanity, they presumably mean a clear and significant benefit. The life-saving good, if any, to be salvaged from the Nazi evil is marginal at best, though its order of magnitude is easily exaggerated by researchers. This exaggeration is not unlike what occurs in the context of defending animal experiments. Exaggerated claims for usefulness are themselves highly unethical, for they stir up painful commotion, anger, and resentment in victimised communities unnecessarily.

In the debate over Nazi data, there is no reason to impugn the intentions of those who have used it in the aftermath of the Holocaust or who would like to in the future. It can be assumed that those on both sides of the debate mean well. However, in the final anaysis medical scientists, even though well-intentioned, should be fully subservient to the principles of autonomy and non-maleficence generally, and should be sensitive to the wishes of those who have been victimised. After an atrocity has been committed, there should as a rule be no use of data. Moreover, the indignation, emotions and thoughts of the victim must be respected in order to indemnify previous lack of respect. Two harms are worse than one: 'enough is enough'.

The author is on the faculty of the School of Medicine, case Western Reserve University School of Medicine, in the Center for Biomedical Ethics. He also holds an appointment in the Department of Philosophy, and is a member of the Society for the Philosophic Study of
Genocide and the Holocaust.

\section{References}

(1) Niebuhr R. What is justice? In: Robertson D B, ed. Love $\frac{\overline{\bar{S}}}{\overrightarrow{\widehat{T}}}$ and justice: selections from the shorter writings of Reinhold ${ }_{\stackrel{Q}{\complement}}$ Niebuhr. Gloucester, Mass: Peter Smith, 1976: 229-231.

(2) Proctor R N. Racial hygiene: medicine under the Nazis. Cambridge, Mass: Harvard University Press, 1988.

(3) Muller-Hill, B. Murderous science. New York: Oxford $\overrightarrow{ }$ University Press, 1988.

(4) Weiss, S F. Race hygiene and national efficiency. Berkeley: University of California Press, 1987.

(5) Lifton R J. The Nazi doctors. New York: Basic Books, $\underset{\sim}{-}$ 1986.

(6) Dixon B. Citations of shame. New scientist 1985; 105: $31 . \vec{\sim}$

(7) Moe K. Should the Nazi research data be cited? Hastings $\hat{\sim}$ Center report 1984; 14: 5-7.

(8) Molner G W. Survival of hypothermia by men immersed in the ocean. Fournal of the American Medical Association 3 1946; 131: 1046-1050.

(9) Fernandez J P, O'Rourke R A, Ewy G A. Rapid active $\frac{\widehat{T}}{\supset}$ external rewarming in accidental hypothermia. Fournal $\vec{C}$ of the American Medical Association 1970; 212: 153-156.

(10) Seidelman W E. In memoriam: medicine's. confrontation with evil. Hastings Center report 1989; 19: 5-6.

(11) Hanauske-Abel H. From Nazi holocaust to nuclear holocaust: a lesson to learn? Lancet 1986; 271 : 8501.

(12) Taylor T. In Trials of war criminals before the Nuremberg $\frac{\circ}{\varnothing}$ military tribunals under control council law no 10. (Vol 1). ․ㅡㄴ Washington, DC: US Government Printing Office, $\overrightarrow{\overrightarrow{0}}$ 1956.

(13) Beecher H K. Ethics and clinical research. New England journal of medicine 1966; 274: 1354-1360. 